\title{
低降伏点鋼の低サイクル疲労特性に関する研究
}

\section{A STUDY ON LOW CYCLE FATIGUE CHARACTERISTICS OF LOW YIELD STRENGTH STEEL}

\author{
佐伯 英一郎*, 杉沢 充**, 山口種 美*** \\ 望月晴雄 $* * * *$, 和田 章***** \\ Eiichiro SAEKI, Mitsuru SUGISA WA, Tanemi YAMAGUCHI \\ Haruo MOCHIZUKI and Akira WADA
}

\begin{abstract}
Recently, studies on seismic energy isolation and damping structures abound and a number of attenuation mechanisms have been proposed. One of them proposes to utilize the elasto-plastic hysteresis of steel, using low yield strength steel as material. This study conducted low-cycle fatigue tests to clarify the low-cycle fatigue characteristics. Hysteresis characteristics and energy absorption characteristics of low yield strength steel will be discussed in the next report. As a result, the following conclusions were obtained concerning low-cycle fatigue characteristics of low yield strength steel.

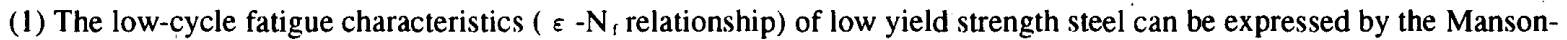
Coffin equation. (2) Despite major differences in static ductility and other properties, low-cycle fatigue characteristics vary little by steel type. (3) The effect of strain rate on low-cycle fatigue characteristics is small. (4) The Monson-Coffin equation's coefficient $C_{1}$ and $m_{1}$ of low yield strength steel deviate from the values obtainable from the conventionally proposed equations. (5) A correlation of $\mathrm{C}_{1}=2.1 / 460^{\mathrm{ml}}$ exists in all types of steel.
\end{abstract}

Keywords:

Low yield strength steel：低降伏点鋼ｌow-cycle fatigue：低サイクル疲労 hysteresis curve：履歴曲線 strain rate: 歪速度

\section{1. まえがき}

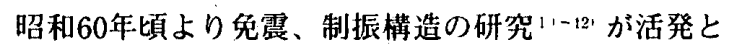
なり多くの振動制御技術が提案されてきた。振動を低減 するには大別すると 2 種類の方法があり、その一つは建 物の剖性を調整することであり、他の一つは建物の隇衰 性の向上にある。減衰性能を向上させることは、言い替 えると人意的にエネルギーを吸収させる機構を建物に装 着させることであり、部材レべル（柱、梁、ブレース） のものから装置的なものまで種々の物が提案されてい る。力学的に分類すると、(1オイルダンパーのように粘 性材料を使用したもの、(粘弾性体を使用したもの、司 摩摖を利用したもの、氙弾塑性履歷を利用したもの等が あげられる。

筆者らは、昭和61年より減衰部材、装䈯（以下ダンバ 一と称す)に利用することを目的として低降伏点鋼の開 発に着手し、成分調整や熱处理等製造法の検討を初めと して種々の力学的確性実駼を実施してきた。従来銅は、
弾性範囲内を強度材として使用するのが一般的であっ た。しかしながら履歴ダンバーとして用いる鋼は、積極 的に塑性域を活用し、塑性域の挙動が重要である。特に 低降伏点鋼については、構造材としでの使用実績がなく 構造上の安全性の確保のために：その力学的特性を明ら かにする必要がある。特に風振動に対する減衰効果を期 待する場合においては、塑性域における疲学特性が問題 となり、地震に対しては歪速度、歪レベルに対応してヒ ステリシスが、どのように変化するかを明らかにしてお く必要がある。

本論文は、低降伏点䤱ひ力学的特性のうち大歪下にお ける低サイクル疲労特性を、歪速度、歪レベルの観点よ り明らがにするとを目的としている。低降伏点鋼の破 壊に至るまでの履歴曲線の特性（降伏点の特性も含む） は紙面の関係上次の報告書の中で論じる。

\section{2. 弾望性ダンパー用鋼材（低降伏点龬）}

履歷隇衰型のダンバーとして使用される鋼材は、地震

本論文の一部は1994年度日本建築学会大会24で発表している。

*新日本製鉄株式会杜 建築事業部 室長 · Nippon Steel Corporation, M. Eng. 工修

**新日本製鉄株式会社 建築事業部 部長代理

*** 新日本製鉄株式会社 建材開発技術部 部長代理·工修

**** 新日本褩鉄株式会社 厚板商品技術室 部長代理 - 工修

***** 東京工業大学 教授・工博

Nippon Steel Corporation

Nippon Steel Corporation, M. Eng.

Nippon Steel Corporation, M. Eng.

Prof., Tokyo Inștitute of Technology, Dr. Eng. 
時に他の柱梁等の構造部材に先行して、かつ設計で想定 した伈カレベルで塑性化することが必要である。他の部 材に先行して塑性化させるためには、形状や使用方法り

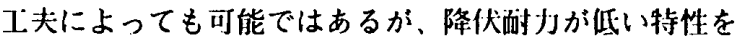
持った鋼材を使用することで、降伏歪も小さくなるため 目的が容易に達成される。このため、まずダンバー用の 龬材としては降伏強さが低いことと、降伏点のばらつき ができる限り狭い範囲に仪まっていること（狭YP）が 要求される。また、地震時にはダンバーは大きな塑性域 における繰返しを受けることになる。このため、低サイ クル疲労特性が重要な問題となる。

䥡の降伏強さを低くし、伸びを高くするためには以下 の三種類のアブローチが考えられる。

1）添加元素を極力低減し純鉄に近いものとする。
2)フェライト結鼠䊉り粗大化

3）他元素等による C. NO鳳定

さらに铜鉝の王延時の最適な温度管理及び必要に応じ て国延け後で稆処理を加えることにより低降伏点蜩は、 製造される。

\section{3. 低サイクル疲労試験方法}

3-1 供試材

試験体は、PURE IRON、LYP100、LYP235(SS400MOD)、SS400（此較用）の4 種類で、その機㑘的性質 と化学成分を表-1に示す、試駼片の記号はPURE IRON をP、LYP100をL、LYP235をH、SS400をSとする。図1(A.B) に応力正線図を示す。PURE IRON、LYP235は、 明睹な降伏点を示すが、LYP100は、降伏点を示さず耐

表-1 供藏材の機械的性質と化学成分

\begin{tabular}{|c|c|c|c|c|c|c|c|c|c|c|c|c|c|}
\hline \multirow[b]{2}{*}{ 供試材名 } & \multirow[b]{2}{*}{ 記号 } & \multicolumn{7}{|c|}{ 引發試験秥果 } & \multicolumn{5}{|c|}{ 化学成分 (\%) } \\
\hline & & $\begin{array}{c}\text { 降伏点 } \\
\left(\mathrm{kg} / \mathrm{mm}^{2}\right)\end{array}$ & $\begin{array}{l}0.2 \% \text { 酎力 } \\
\left(\mathrm{kg} / \mathrm{mm}^{2}\right)\end{array}$ & $\begin{array}{l}\text { 引舆強さ } \\
\left(\mathrm{kg} / \mathrm{mm}^{2}\right)\end{array}$ & $\begin{array}{c}\text { 降伏比 } \\
(\%)\end{array}$ & $\begin{array}{l}\text { 伸び } \\
(\%)\end{array}$ & $\begin{array}{c}\text { 絞り } \psi \\
(\%)\end{array}$ & $\begin{array}{l}\text { 静破断 } \varepsilon_{i}^{*} \\
\text { 延性 }(\%)\end{array}$ & $\mathrm{C}$ & $\mathrm{Si}$ & $\mathrm{Mn}$ & $\mathbf{P}$ & $\mathbf{S}$ \\
\hline LYPIO0 & $\mathrm{L}$ & - & 13.5 & 27.6 & 48.8 & 58.4 & 89.5 & 226 & 0.002 & 0.02 & 0.16 & 0.01 & 0.01 \\
\hline $\begin{array}{l}\text { PURE } \\
\text { IRON }\end{array}$ & $P$ & $\begin{array}{cc}\text { 上 } & 19.2 \\
\text { (下 } & 16.9)\end{array}$ & - & 28.4 & $\begin{array}{c}67.6 \\
(59.5)\end{array}$ & 65.8 & 91.2 & 243 & 0.003 & 0.003 & 0.13 & 0.01 & 0 \\
\hline LYP235 & H & $\begin{array}{cc}\text { 上 } 29.6 \\
\text { (下 } 24.5)\end{array}$ & - & 32.7 & $\begin{array}{c}90.0 \\
(74.9)\end{array}$ & 50.8 & 81.4 & 168 & 0.04 & 0.02 & 0.25 & 0.01 & 0.01 \\
\hline SS400 & $S$ & $\begin{array}{cc}\text { 上 } & 27,0 \\
(\text { 下 } & 26,0)\end{array}$ & - & 46.6 & $\begin{array}{c}58.1 \\
(55.8)\end{array}$ & 44.6 & 70.2 & 121 & 0.15 & 0.215 & 0.99 & 0.02 & 0 \\
\hline
\end{tabular}

$* \varepsilon_{\mathrm{f}}=\ln \frac{100}{100-\%} \times 100(\%)$

(真破断歪とも急う)
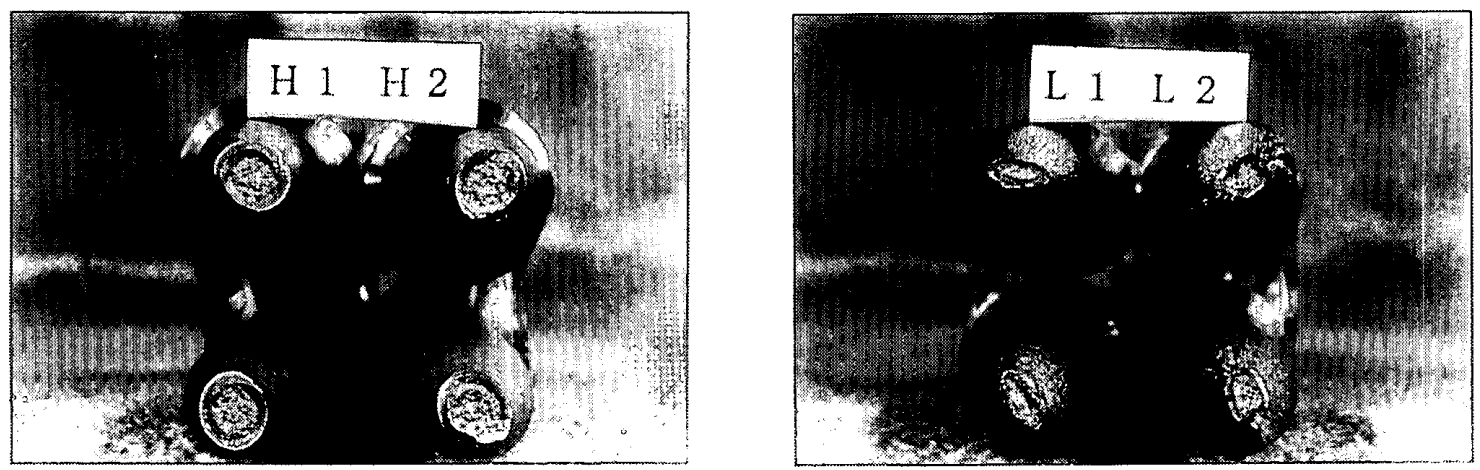

(L)

写真-1 引張試験片の破断状況

(H)
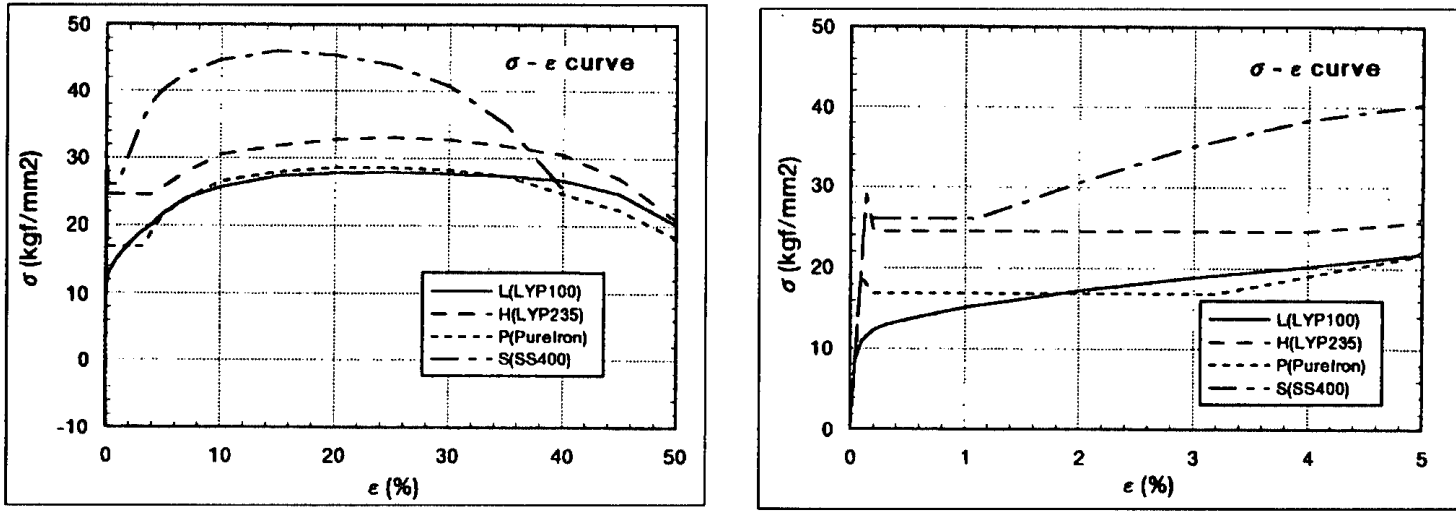

(A)

図-1 㐫心霍線図

(B) 


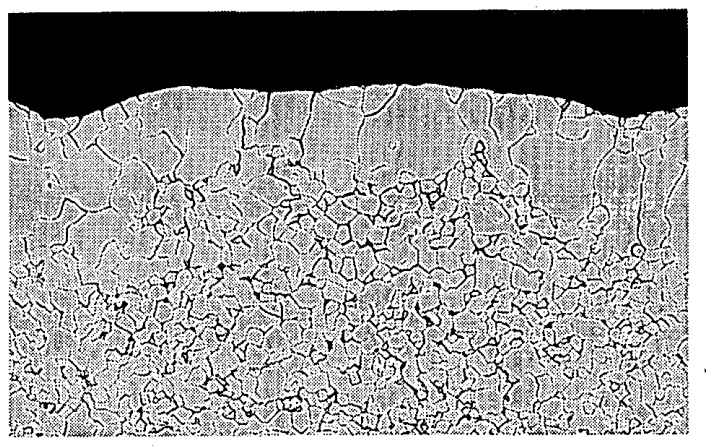

写真-2 断面組織 $(\mathrm{H})$

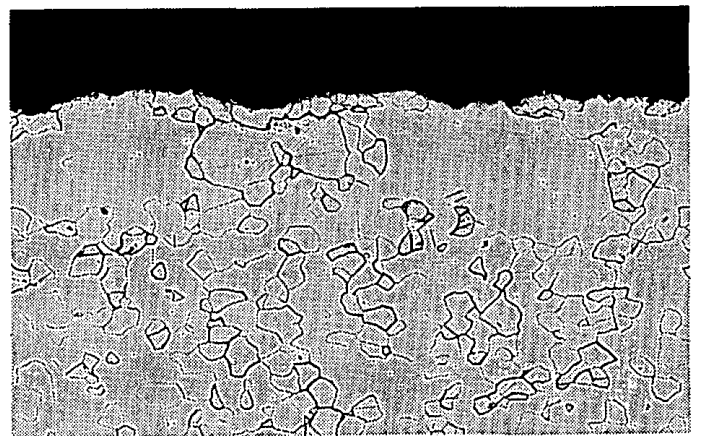

写真-3 断面組織（L)

力が低く降伏比も低い。LYP2350降伏伸びはSS400に比 較して著しく大きいがLYP100、PURE IRONの伸びはさ らに大きく、破面写真 (写真-1) でもわかるように絞 りもいちじるしく大きい。

写真-2、3に、LYP235、LYP1000各試験片の表層と $1 / 2 \mathrm{t}$ のミクロ組織を示す。㩆微鏡写真の倍率は、 LYP235が100倍、LYP100が50倍である。LYP235は表垬 層の椣表面の組織は粗粒となっているが、他の大部分は 小さい整粒となっている。一方、LYP1000)組織は、㮒 表層はLYP235と同じであるが $1 / 4 \mathrm{t}$ から $3 / 4 \mathrm{t}$ の間に 最大亏 $\mathrm{mm}$ 位の粗大結唱粒が存在し、他心部分も混粒と なっていて粗大結晶粒が散在している。

\section{3-2 試験方法}

低サイクル試験片は図ー2に示すように平行部は㨁径 $10 \mathrm{~mm}$ 、唇さ $22 \mathrm{~mm}$ であり、表面は軸方向に600番エメリ ーベーパーで仕上げた。低サイクル摭労試験機は、10：

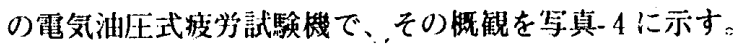

試験条件は次のと捛りである。

制御：軸页制御（コンピュータ制御）

標点距離: $15 \mathrm{~mm}$

歪比 $: \mathrm{R}\left(\varepsilon_{\max } / \varepsilon_{\text {min }}\right)=-1 \quad$ (完全迁振り $)$

測定項目：侕重、変位、変位速度、繰返し回数 破断繰返し数 $\left(\mathrm{N}_{i}\right)$ ：荷重が最大衍重の75\%に低 下した時ひ繰返し回数

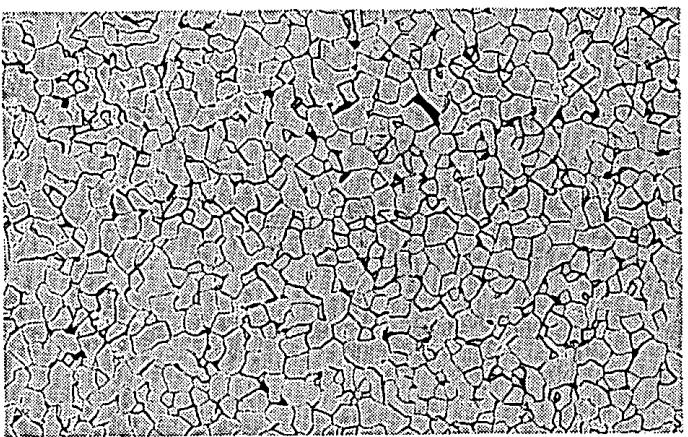

（左：表層、右： $1 / 2 \mathrm{t}$ )

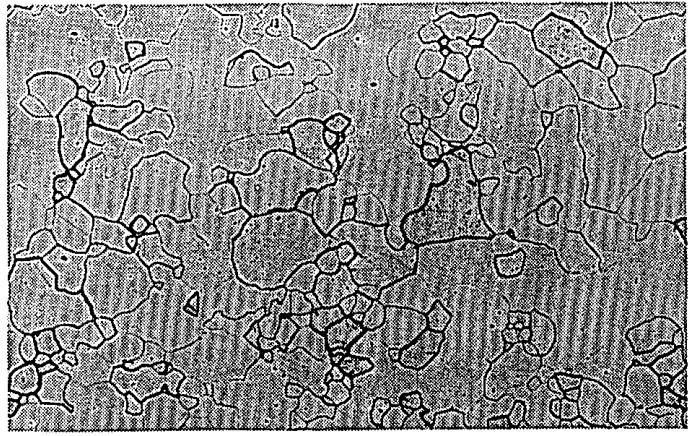

（左：表䁌、右：1/2t）

\section{3-3 芸験の種類}

試験は囸速度、全歪䡉国をバラメーターとして実施し た。低降伏点鋼は先に述べた様に、免震、制振用弾盟性 ダンパーとして使用されるわけであるが、その最大歪範 闻、最大歪速度の範囲を次のように考えた。モデルディ バイスとして免震タンン゙ー（図-3)、アンボンドブレー ス（罒-4）を例にとる。

免震ダンバーは免震層の最大層間変位を $20 \mathrm{~cm} 、 1$ 次 固有周期を 2 〜秒として正弦振動を仮定するならばタ ンバーに発生する最大昰は土 $2 \%$ 、最大䄳速度は $5 \% /$ secである。アンボンドブレースの場合、層間変形を
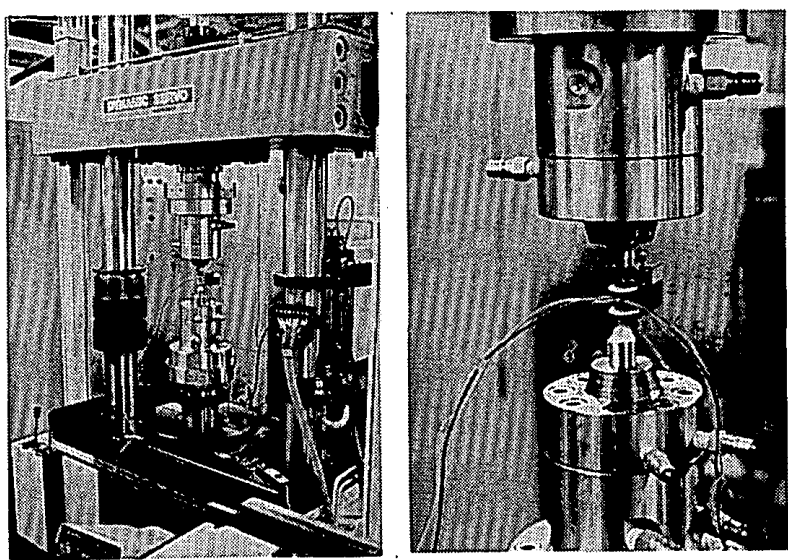

写真-4 低サイクル痩学試験機 
1／100、建物の一次固有周期を同様に $2-3$ 秒と仮定し て歪が長さ方向に一様に分布するという前提で計算する と最大歪は土1.0\%、最大歪速度 $2.5 \% / \mathrm{sec}$ となる。従っ て上記の数値を参考にして試験の種類は、表- 2 に示す ものとした。

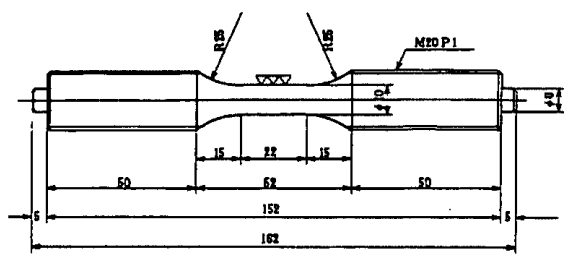

図-2 低サイクル疲学試験片形状

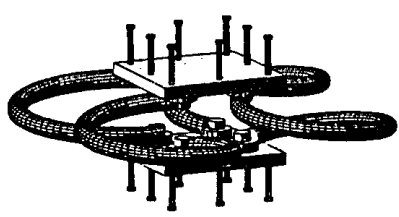

図-3 スチールダンバー

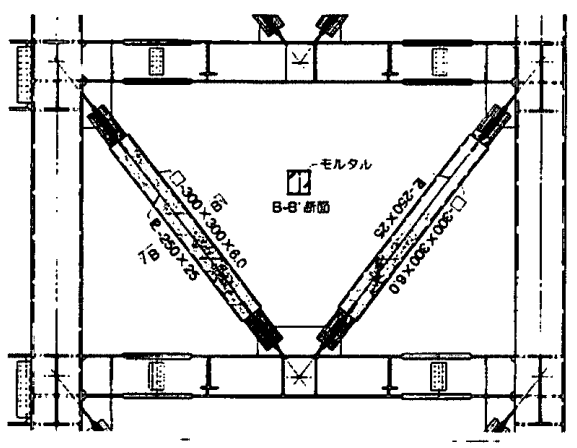

困-4 アンボンドフレース
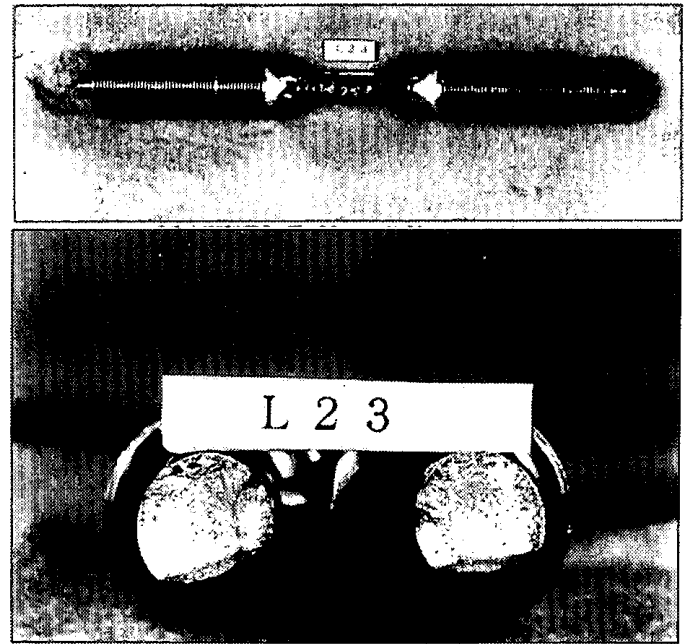

写真-5 低サイクル疲学皮断の状沇 (L)

\section{$3-4$ 試験絬果}

試験絬果ひ一例を図-5、6に示す、ヒステリシスルー ブは、安定した結鍾形を示し、处女ルーブ以降は4ーラ サイクルでほほ同一のルーブを描く。

颁女載何時のヒステリシスルーブは図７のようにモ デル化でき、初期引張過程と初期压縮過程に大別できる。 初期引張過程の㐫力歪関係は引張試験と同一のもので、 降伏点の存在するもの（PURE IRON,LYP235,SS400）は、 降伏点が現われ、存在しないもの（LYP100）法現われ ない。降伏点の值（A、a、A）は、昰速度に影響され、 その特性については、次ひ報告で考察する。初期圧樎過 程（B 1、C、D、E）は、引張時と同じ弾性勾配で変形 し、バウシンガー効果で早期に塑性変形を起こし（C)、 歪碓化を起こしながら初期圧縮最大荷重（E）に達する。 第2引張過程（E、F、G、B 2）に打いては、降伏点 は睍われずB 2に扎いて初期引張過程（B1）より高い

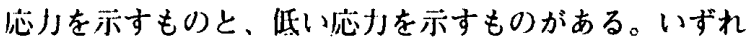
け場合も、初期繰返し軟化あるいは繰返し硬化を起こし ながら4ーラサイクルで定常状態のヒステリシスルーブ に収束し、破断の直欮まで安定したルーブを示す。

図-7（C）は定常状態のヒステリシスルーブモデルを 示しておう、全歪範囲を $\varepsilon_{\mathrm{t}}$ 、弾性歪範囲 $\varepsilon_{\mathrm{e}}$ 、㕵性歪籍 囲 $\varepsilon_{\mathrm{p}}$ 、歪振幅 $\varepsilon_{\mathrm{a}}$ 及び㐫力振幅 $\sigma_{\text {max }}$ 汹図のように定䉝 する。

表-2 試験の種類

\begin{tabular}{|c|c|c|c|c|c|c|c|c|c|c|c|}
\hline & \multicolumn{10}{|c|}{ 全垔 籍 两 $\varepsilon_{t}(\%)$} \\
\hline & & 0.3 & 0.4 & 0.5 & 0.6 & 0.7 & 0.8 & 1 & 1.5 & 2 & 3 \\
\hline \multirow{6}{*}{$\left|\begin{array}{c}\text { 速度 } \\
\dot{\varepsilon} \\
(\% / \mathrm{sec}\end{array}\right|$} & \multirow{4}{*}{0.1} & & $\mathrm{~L}$ & $\mathbf{L}$ & & $\mathrm{L}$ & & $\mathrm{L}$ & $\mathrm{L}$ & $\mathrm{L}$ & \\
\hline & & & $\mathrm{H}$ & $\mathrm{H}$ & & $\mathrm{H}$ & & $\mathrm{H}$ & $\mathrm{H}$ & $\mathrm{H}$ & $\mathrm{H}$ \\
\hline & & $P$ & $\mathrm{P}$ & $\mathbf{P}$ & P & & $P$ & $P$ & $P$ & $\mathrm{P}$ & \\
\hline & & $\mathrm{S}$ & $\mathrm{S}$ & $\mathrm{S}$ & $\mathrm{S}$ & & $S$ & $\mathrm{~S}$ & $\mathrm{~S}$ & $\mathrm{~S}$ & \\
\hline & \multirow{2}{*}{5.0} & & $\mathrm{~L}$ & $\mathrm{~L}$ & & L & $\mathrm{L}$ & $\mathrm{L}$ & $\mathrm{L}$ & $\mathrm{L}$ & \\
\hline & & & $\mathrm{H}$ & $\mathrm{H}$ & & $\mathrm{H}$ & $\mathrm{H}$ & $\mathrm{H}$ & $\mathrm{H}$ & $\mathrm{H}$ & $\mathrm{H}$ \\
\hline
\end{tabular}
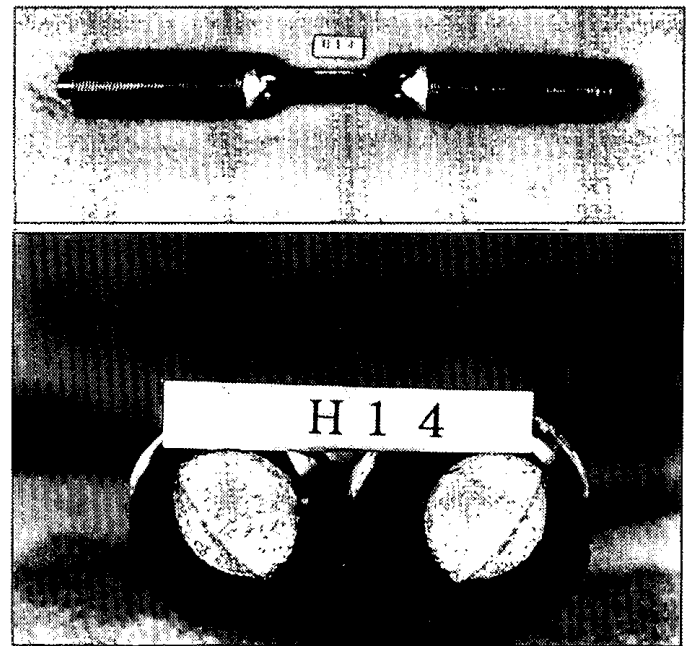

写真-6 低サイクル疲学破断の状況（H） 


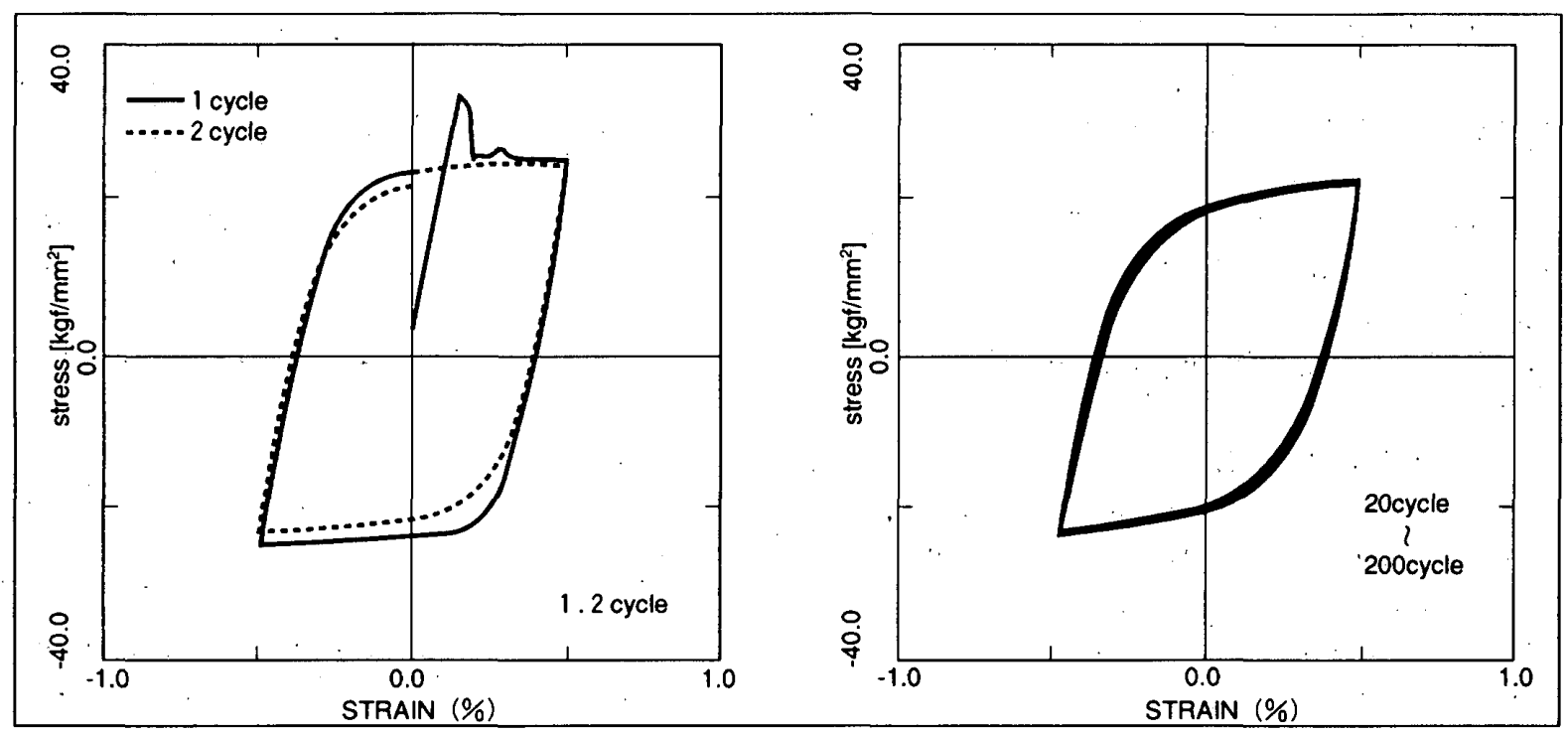

図-5 試験結果 $\left(\mathrm{H}, \dot{\varepsilon}=0.1 \% / \mathrm{sec}, \varepsilon_{\mathrm{t}}=1.0 \%\right)$

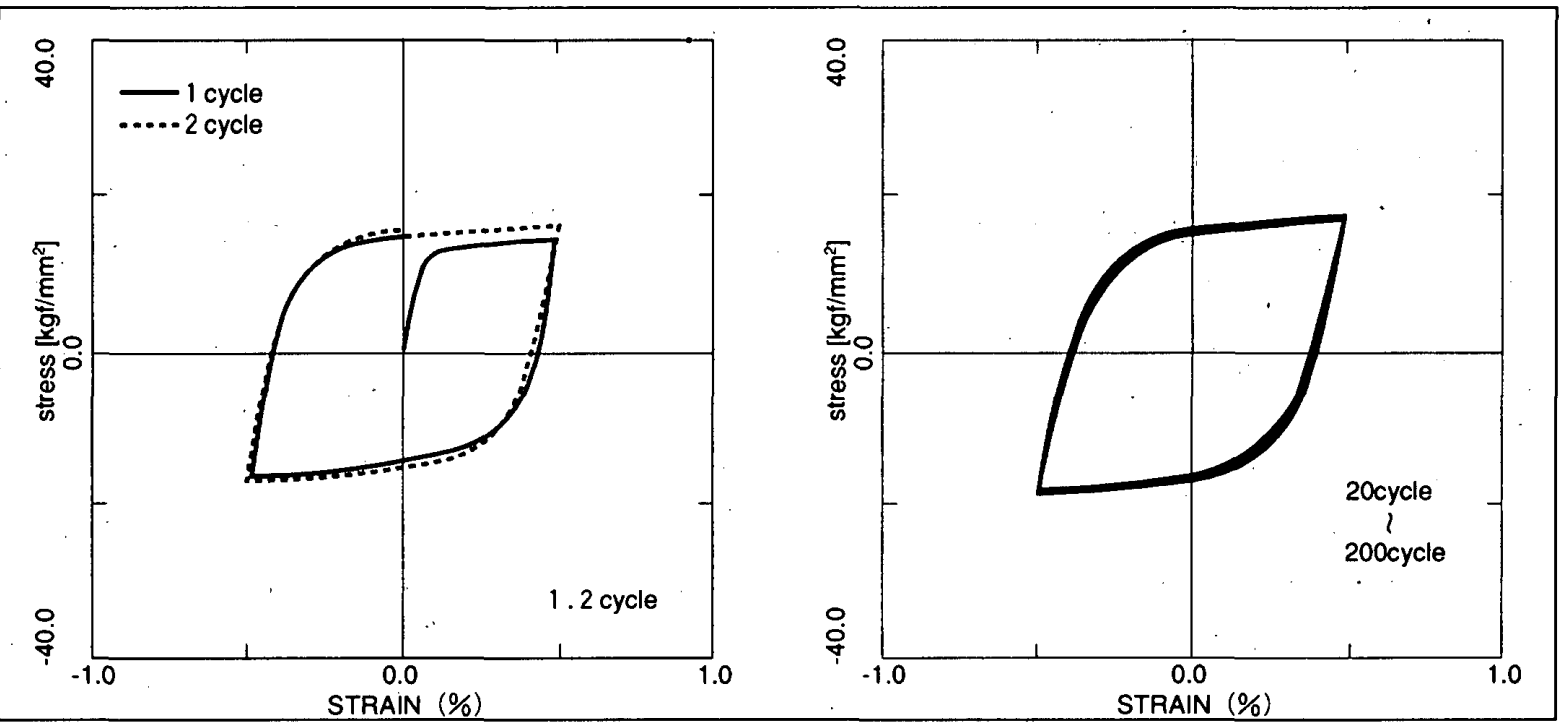

図-6 試験結果 $\left(\mathrm{L}, \dot{\varepsilon}=0.1 \% / \mathrm{sec}, \varepsilon_{\mathrm{t}}=1.0 \%\right)$
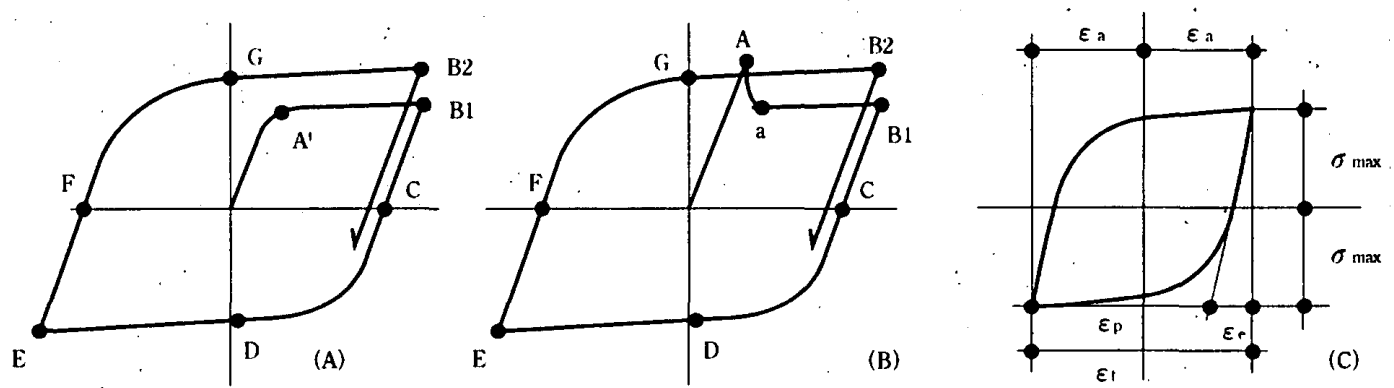

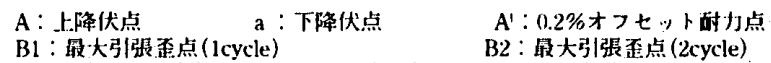

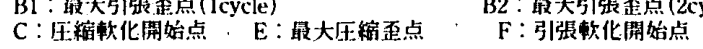

図-7 ヒステリシスループモデル 
3-5 破断状涗のミクロ組織

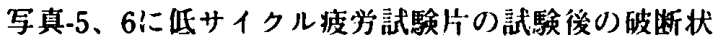
洗と破面状況の一例を示す。塑性変形による肌荒れや轧 裂の発生状況からみるとLYP235に比較してLYP100の絬 晶粒は非常に粗いことがわか。LYP100は摭学破面が 進展してからせん断破壊をしており、疲労䈉発生点付 近の破面の粗いものが多い。粗大結晶粒が低サイクル疲 労寿命に影幚を与えている可能性が大きい。

\section{4. 低サイクル疲労樲験結果}

図-8〜13にそれぞれの铜材の䄳範囲とと破断繰返し

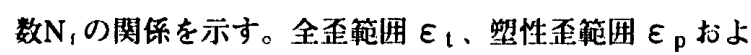
び弾性歪範囲 $\varepsilon_{\mathrm{e}}$ は、 $\varepsilon_{\mathrm{t}}=\varepsilon_{\mathrm{p}}+\varepsilon_{\mathrm{e}}$ なる関係があり接 労試験では $\varepsilon_{\mathrm{t}}$ を制御している。Manson-Coffin 式は、 次式で表わされる。

$$
\begin{aligned}
& \varepsilon_{\mathrm{p}}=\mathrm{C}_{1} \cdot \mathrm{N}_{\mathrm{1}} \mathrm{m} \\
& \varepsilon_{\mathrm{e}}=\mathrm{C}_{2} \cdot \mathrm{N}_{\mathrm{t}}{ }^{\mathrm{m} 2} \\
& \varepsilon_{\mathrm{t}}=\mathrm{C}_{1} \cdot \mathrm{N}_{\mathrm{1}}{ }^{\mathrm{ml}}+\mathrm{C}_{2} \cdot \mathrm{N}_{1}{ }^{\mathrm{m} 2}
\end{aligned}
$$

上に示す式を用いて本試験結果を回帰すると次のよう な実験式を得る。

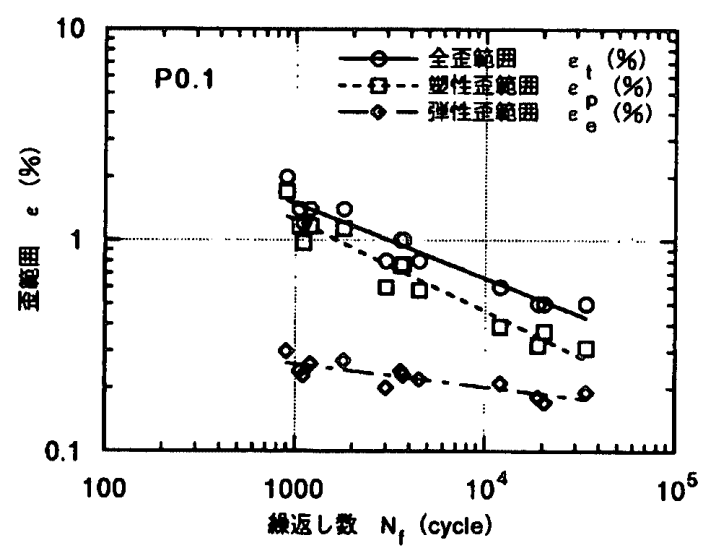

図-8 等範囲 $(\varepsilon)$ 一破断綝返し数 $\left(\mathrm{N}_{\mathrm{t}}\right)$

(P、 $\dot{\varepsilon}=0.1 \% / \mathrm{sec}$ )

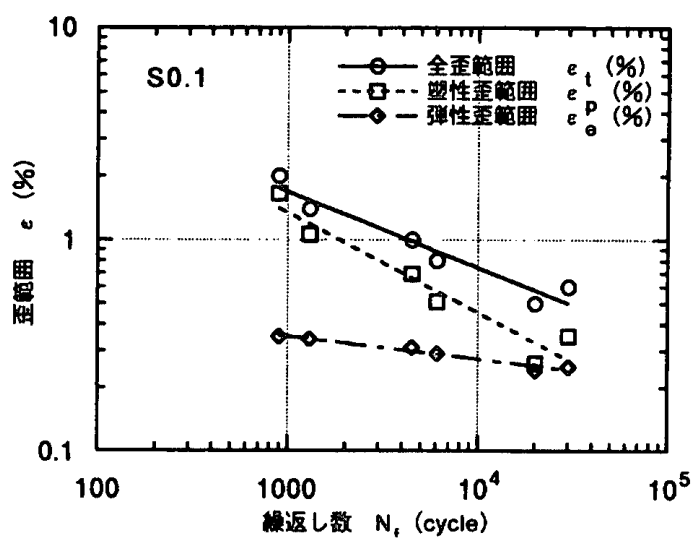

図-10 歪笧网 $(\varepsilon)$ 一破断繰返し数 $\left(\mathrm{N}_{1}\right)$

(S、 $\dot{\varepsilon}=0.1 \% / \mathrm{sec}$ )
LYP235

$$
\begin{array}{ll}
\dot{\varepsilon}=0.1 \% / \mathrm{sec} & \varepsilon_{\mathrm{t}}=72 \mathrm{~N}_{\mathrm{t}}{ }^{-0.55}+0.88 \mathrm{~N}_{\mathrm{t}}{ }^{-0.14} \cdots \cdots(4) \\
\dot{\varepsilon}=5.0 \% / \mathrm{sec} & \varepsilon_{\mathrm{t}}=184 \mathrm{~N}_{\mathrm{t}}-0.67+0.47 \mathrm{~N}_{\mathrm{t}}^{-0.077} \cdots(5)
\end{array}
$$

BT-LYP100

$$
\begin{array}{ll}
\dot{\varepsilon}=0.1 \% / \mathrm{sec} & \varepsilon_{\mathrm{t}}=33 \mathrm{~N}_{\mathrm{t}}^{-0.48}+0.47 \mathrm{~N}_{\mathrm{t}}^{-0.0 .187 \cdots \cdots(6)} \\
\dot{\varepsilon}=5.0 \% / \mathrm{sec} & \varepsilon_{\mathrm{t}}=328 \mathrm{~N}_{\mathrm{f}}^{-0.79}+0.37 \mathrm{~N}_{\mathrm{t}}^{-0.073 \cdots(7)}
\end{array}
$$

PURE IRON

$$
\dot{\varepsilon}=0.1 \% / \mathrm{sec} \quad \varepsilon_{\mathrm{t}}=24 \mathrm{~N}_{\mathrm{t}}{ }^{-1.42}+0.56 \mathrm{~N}_{\mathrm{t}}{ }^{-0.11} \cdots \cdots(8)
$$

SS400

$$
\dot{\varepsilon}=0.1 \% / \mathrm{sec} \quad \varepsilon_{\mathrm{t}}=35 \mathrm{~N}_{\mathrm{f}}{ }^{-0.47}+0.74 \mathrm{~N}_{\mathrm{t}}-0.11 \cdots \cdots(9)
$$

\section{4-1鋼種による差璂}

図-14:全鋼種の全歪範困 $\varepsilon_{\mathrm{t}}(\%)$ と破断繰这し数

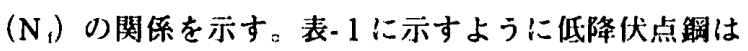
SS400と比較して非常に大きな破断延性を有するにも拘

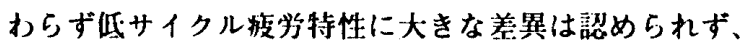
どちらかと言うと降伏点が小さい材種は疲学寿命が短 い䛧向がある。

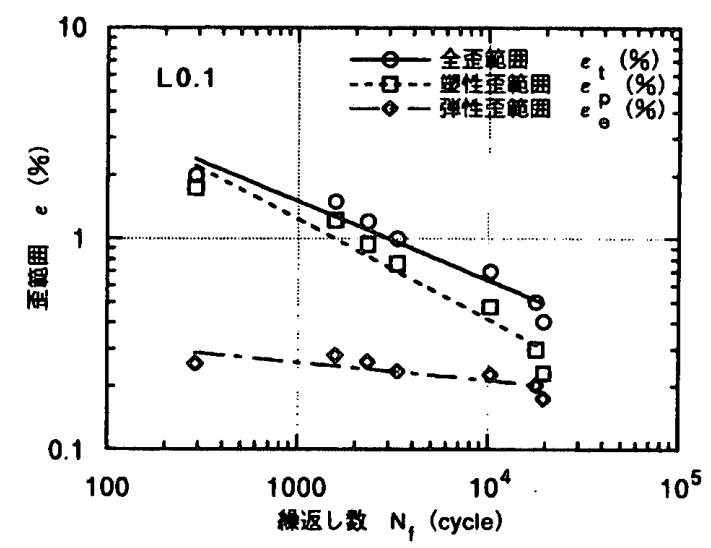

図-9 䄳範囲 $(\varepsilon)$ 一破断繰返し数 $\left(\mathrm{N}_{1}\right)$

(L、 $\dot{\varepsilon}=0.1 \% / \mathrm{sec}$ )

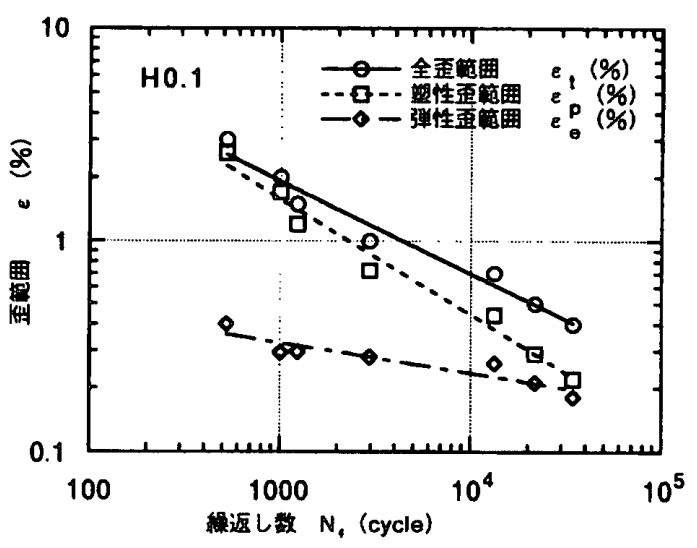

图-11 歪範囲 $(\varepsilon)$ 一破断綝返し数 $\left(\mathrm{N}_{1}\right)$

(H、 $\dot{\varepsilon}=0.1 \% / \mathrm{sec}$ ) 


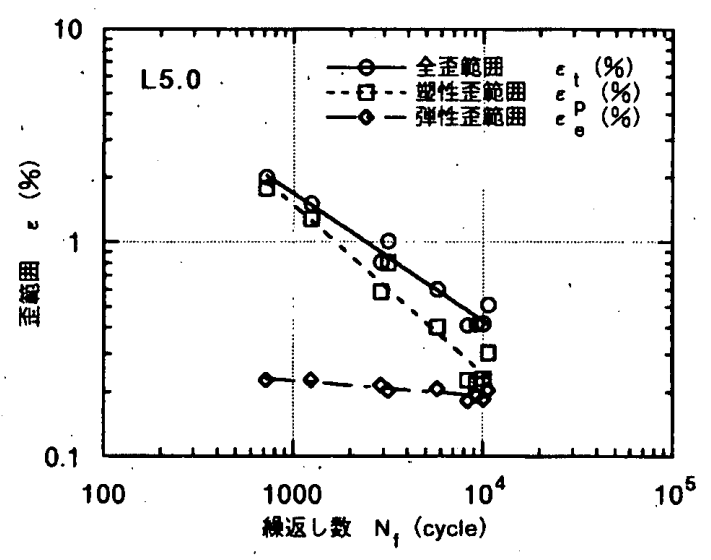

図-12 歪範围 $(\varepsilon)$ 一破断綝返し数 $\left(\mathrm{N}_{\mathrm{i}}\right)$

(L, $\dot{\varepsilon}=5.0 \% / \mathrm{sec}$ )

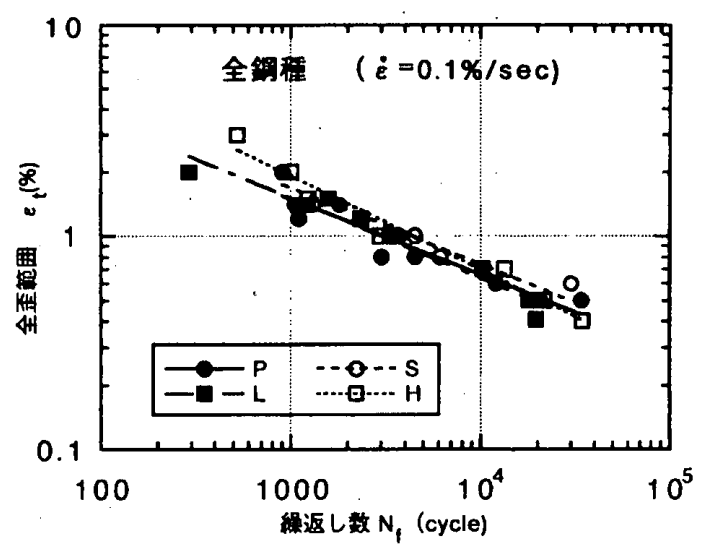

目-14 全歪範囲 $(\varepsilon)$ 一破断綝返し数 $\left(\mathrm{N}_{1}\right)$

(全鋼種、 $\varepsilon=0.1 \% / \mathrm{sec}$ )

\section{$4-2$ 惒速度の影響}

図-15.16にH、Lについて昰速度の異なる2試験の $\varepsilon_{\mathrm{t}}-\mathrm{N}_{\mathrm{f}}$ 関係を示している。Lの高サイクル域で多少の 差暴は認められるものの、低サイクル摭垺寿命に及す䄳 速度の影幚は小さいことがわかる。

\section{4-3 低サイクル疲学と静的引張特性}

低サイクル接学特性を简便に推定・評伍するために、 静的引張特性との関連性に関する研究が数多くある131-18: すなわち(1).(2) 式の指数、係数と引張特性との関係式 がいくつか提案されている。

Manson ${ }^{15:}$ は多くの材料の平均として、 $\mathrm{m}_{1}=-0.6$ とし、 係数 $C_{1}$ は材料の静破断延性 $\varepsilon_{\mathrm{f}}$ に関係忖什て、 $\mathrm{C}_{1}=\varepsilon_{\mathrm{f}}{ }^{0.6}$ なる関係を提案している。さらに、C 表わして(3) 式の推定式として次式を導出した。

$$
\varepsilon_{\mathrm{t}}=\varepsilon_{\mathrm{f}}{ }^{0.6} \cdot \mathrm{N}_{\mathrm{f}}^{-3.6}+3.5\left(\sigma_{\mathrm{u}} / \mathrm{E}\right) \cdot \mathrm{N}_{\mathrm{f}}^{-3.12 \cdots(10)}
$$
たたし

$\varepsilon_{\mathrm{f}}=\ln (100 /(100-\psi)) \times 100 \quad(\psi:$ 絞り $(\%))$

Coffin ${ }^{181}$ は、静的引張訆験は $\varepsilon_{\mathrm{p}}=2 \cdot \varepsilon_{\mathrm{f}} 、 \mathrm{R}=-1$ な

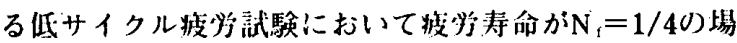

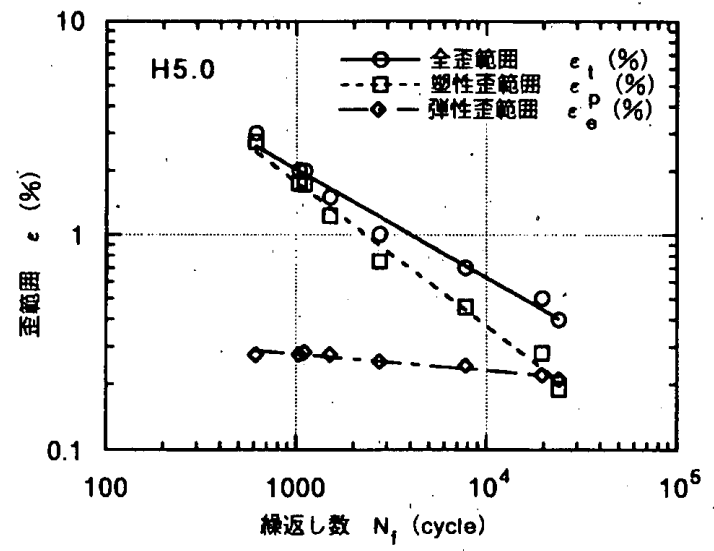

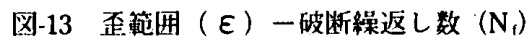

(H、 $\dot{\varepsilon}=5.0 \% / \mathrm{sec}$ )

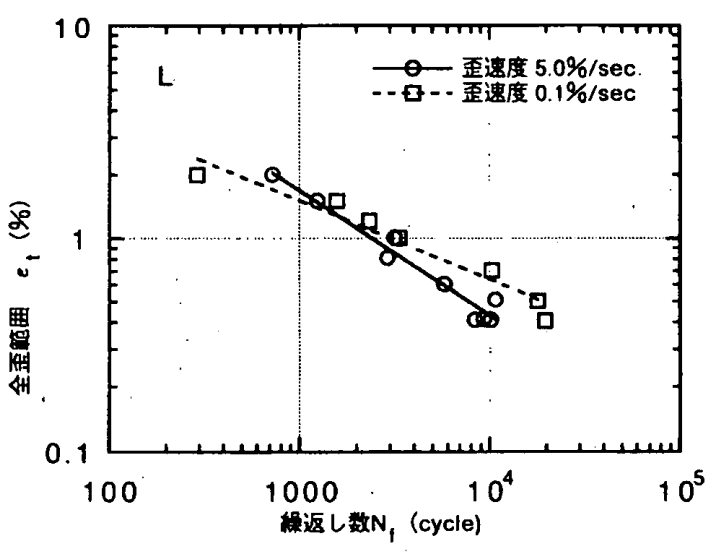

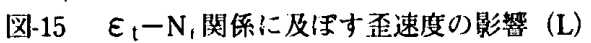

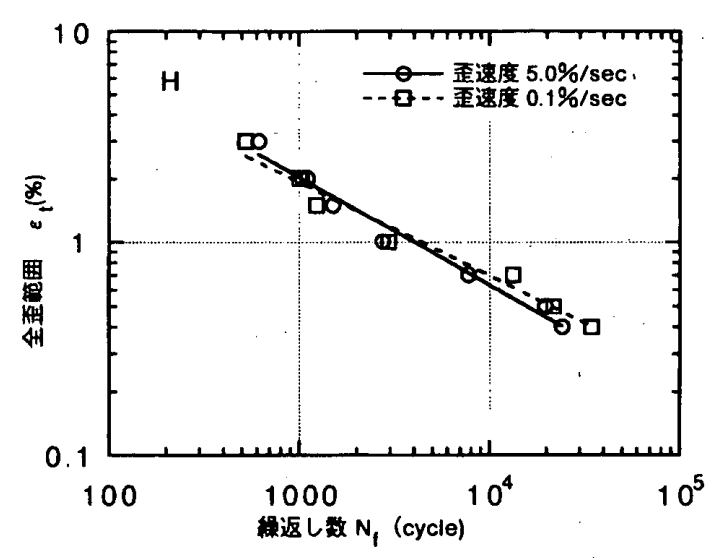

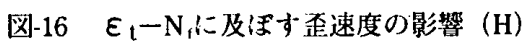

合に相当すると考元、 $\mathrm{m}_{1}=-0.5 、 \mathrm{C}_{1}=2 \cdot \varepsilon_{\mathrm{f}}$ を提案して いる。また、Martin'はヒステリシスエネルギーの観 点から $\mathrm{m}_{1}=-0.5 、 C_{1}=\varepsilon_{\mathrm{f}} / \sqrt{2}$ を導出した。

このように、いずれの提案式においても $\varepsilon_{\mathrm{f}}$ が大きい 程C、は大きくなる。低降伏点䟖はSS400に比べて非常に 大きな静破断延性を有するにも拘わらず、図-14に見ら れるように低降伏点鎆の $\varepsilon_{\mathrm{p}}-\mathrm{N}$ (関俰はSS4000)それに 
比べて良くはなっていない。このため、他の鎆材の完全 两振り歪制御低サイクル疫学試験結果 ${ }^{23}$ : より各㮔材料 の $\mathrm{C}_{1}$ と $\mathrm{m}$ を比較する。

図-17に $\varepsilon_{\mathrm{f}}$ と $\mathrm{C}_{1} 、 \mathrm{~m}_{1}$ の関俰を示すが、Manson, Coffin, Martinらの提案式との明暸な相関性は諗められ ない。一方、 $C_{1} 、 と \mathrm{~m}$, 間には図-18に示すように良い 相関が見られ、 $C_{1}=2.1 / 460^{\mathrm{m}}$ と表わされる。このこと

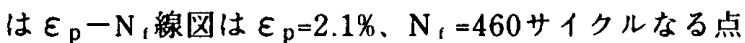
(pivot) を通る事を示している。

図-19に $\mathrm{N}_{\mathrm{t}}=10^{3} 、 10^{4}$ 回の時の $\varepsilon_{\mathrm{t}}$ と $\varepsilon_{\mathrm{f}}$ の関係、図-20に は同じ $\varepsilon_{\mathrm{t}}$ と引張強度 $\sigma_{\mathrm{u}}$ の関係を示す。これらの図にお

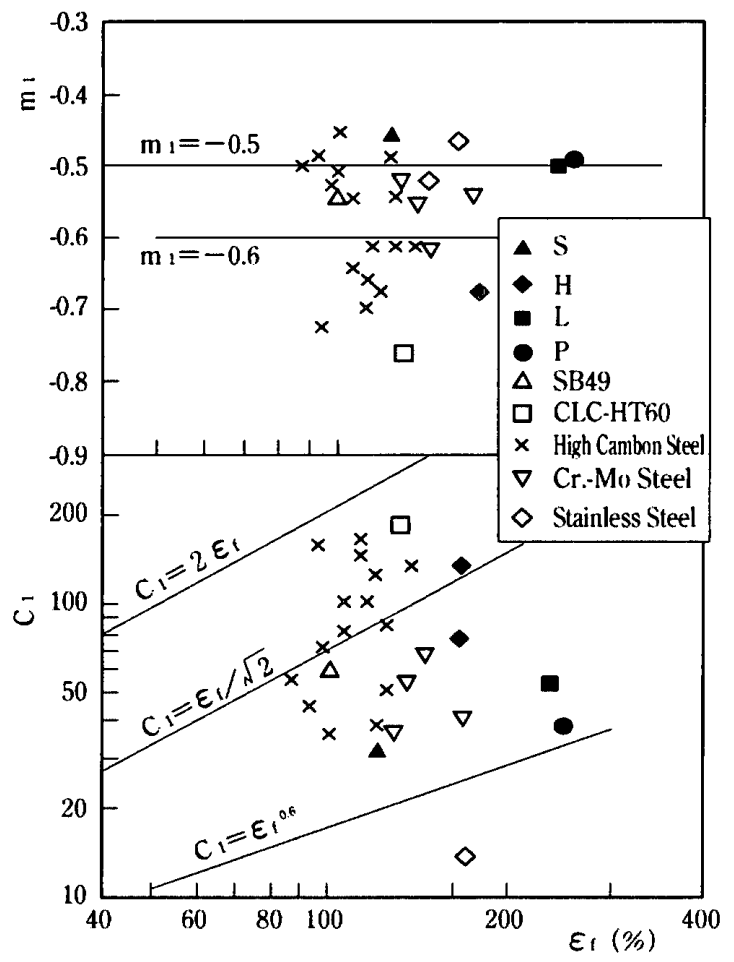

図-17 静破断延性 $\left(\varepsilon_{\mathrm{f}}\right)$ と係数 $\mathrm{C}_{1}$ 、指数 $\mathrm{m}_{1}$ O)関係

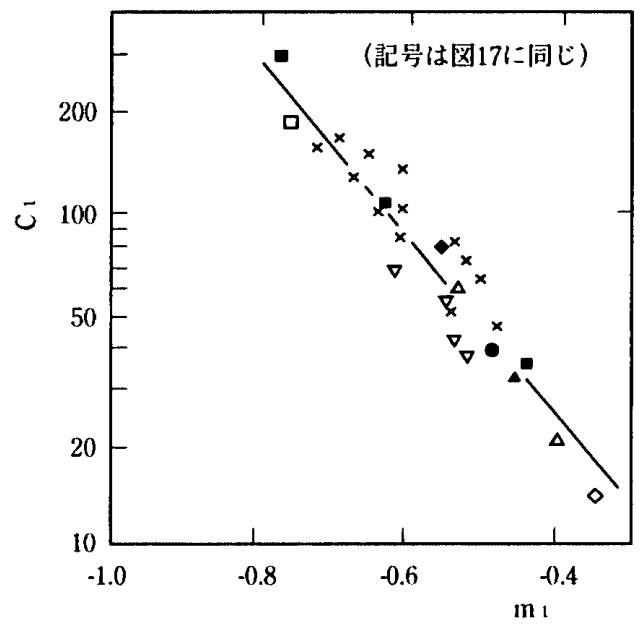

図-18 係数 $\mathrm{C}_{1}$ 、指数 $\mathrm{m}_{1}$, ) 関係
いて、低サイクル疲労強度と $\varepsilon_{\mathrm{f}} 、 \sigma_{\mathrm{u}}$ の間心強い相関 関係は認められない。特に図-19では $\varepsilon_{\mathrm{f}}$ が大きくなると $\varepsilon_{\mathrm{t}}$ がやや小さくなる㑯问が見られ、Coffin、Mansonら の研究結果から予想される傾向とは異なっている。

\section{5. 結論}

普通鋼（SS400）及び低降伏点鎆の低サイクル疲労試 験を実施し、以下のような結論を得た。

(1) 低降伏点鋼 $)$ 低サイクル疲学特性 $\left(\varepsilon-\mathrm{N}_{\mathrm{t}}\right.$ 関係) はManson-Coffin式で表晛できる。

（2）破断延性等に大きな差異があるにもかかおらず、低

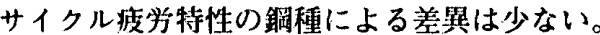

（3）低サイクル度労特性に及ぼす歪速度の影響は小さい。

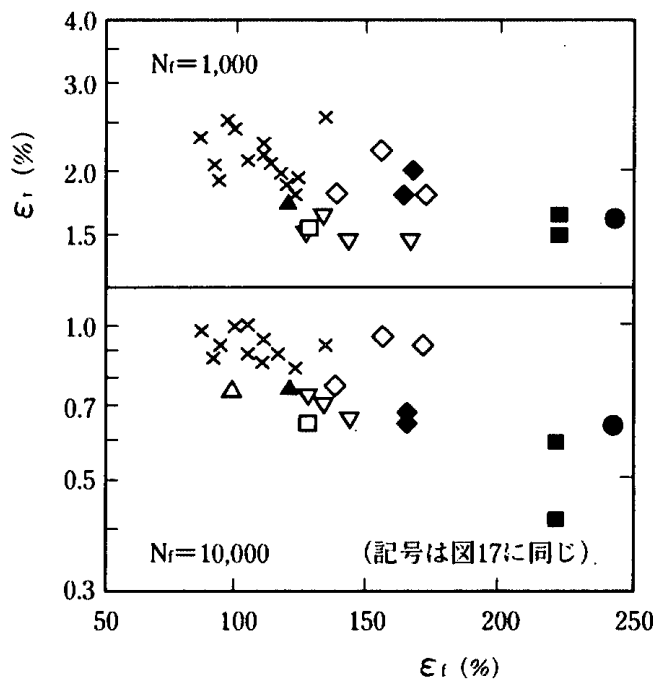

図-19 静破断延性 $\left(\varepsilon_{\mathrm{f}}\right)$ と全歪笵囲 $\left(\varepsilon_{\mathrm{t}}\right)$ 0)関倸

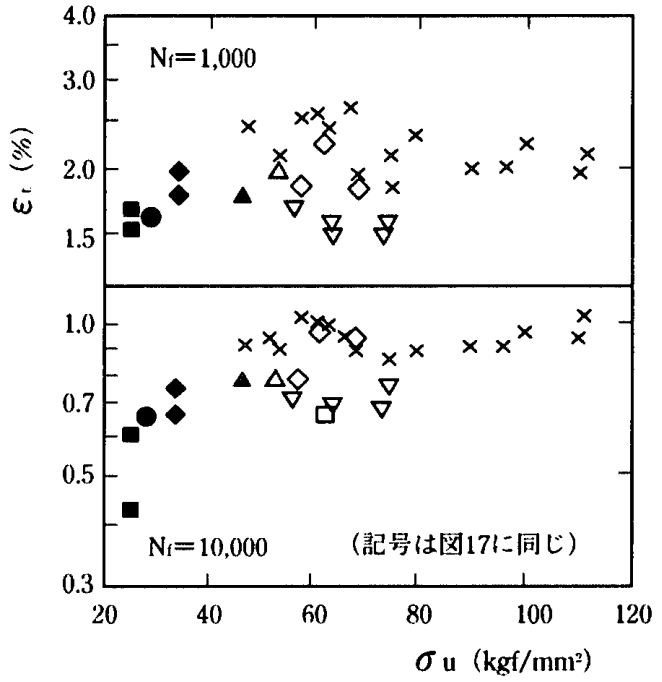

図-20 引張強度 $\left(\sigma_{\mathrm{u}}\right)$ 全歪範囲 $\left(\varepsilon_{\mathrm{t}}\right)$ 0)関係 
（4）低降伏点鋼の) Monson-Coffin式の係数 $\mathrm{C}_{1} 、 \mathrm{~m}_{1}$ は従来 の提案式との相関は認められず特に静破断延性 $\varepsilon_{\mathrm{f}}$ との 相関は認められない。

(5) $\mathrm{C}_{1}$ と $\mathrm{m}_{1}$ には $\mathrm{C}_{1}=2.1 / 460^{\mathrm{m}_{1}}$ なる相関がある。これ はすべての鋼材の $\varepsilon_{\mathrm{p}}-\mathrm{N}_{\mathrm{r}}$ 線図において、 $\varepsilon_{\mathrm{p}}=2.1 \%$ 、 $\mathrm{N}_{1}=460$ なるPivot点が存在することを意味している。 竧辞

本研究にあたり、新日鉄(侏) 厚板破壊研究部征矢主幹 研究員及び株!相模精機半澤貢殿に御協力頂くと共に賃 重な御意見を頂いた。

付記して感謝の意を表します。

\section{参考文献}

1）小堀 他:ハニカム開口を有する鋼板ダンバーに関 する研究（その1一その6）。日本建築学会大会梗概 集、1989 1992.8

2）三浦 他：ハニカムダンバを使用した高層ビル。ビ ルディングレター 1991.2

3）大西 他：鋼製ダンパーを用いた高層 $\mathrm{RC}$ 造建物ひ 設計と施工，コンクリート工学、Vol.31、No.10、 1993.10

4）細沢 他：極低降伏点鋼材の輹歷減衰による制振シ ステム、日本建築学会関東支部研究報告集、1990

5）泉他：極低降伏点鐥を用いたせん断降伏型制振部 材の低サイクル疲学実験（その1〜4）、日本建築学 会大会梗概集、1992.8、1993.9

6）極低降伏点鋼材を利用した制振システム，建築技術、 1993.11

7）花井 他：低降伏伈力度鋼を用いたK型ブレース制 振装置に関する研究（その1〜その5）。日本建築学 会大会梗概果、1991.9、1992.8、1993.9

8）花井 他：低降伏応力度鋼を用いたX型ブレース制 振装置付架構の弾塑性性状（その1その3），日本 建築学会大会梗概集、1993.9

9）中村 他：鋼管の㨝れ降伏を利用した滥塑性ダンバ 一に関する研究（そひ1２），日本建築学会大会梗 概集、1993.9

10）渡辺 他：被害レベル制御設計法の研究（その1 そけ4）、日本建筑学会大会梗概集、1992.8、1993.9

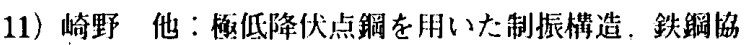
会 CAMP-ISU Vol.5、1992

12）三山他：撴低降伏点釦を用いた制振㩐造に関する 研究 $($ そ01２），日本建筑学会大会㮴概集、 1993.9

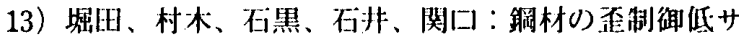
イクル疲学強度推定に関する研究(第1㪇). 日本造 船学会論文集 No.124（1968）p.341 p.353

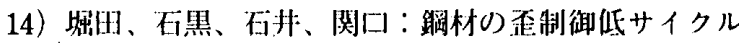

疲学強度推定に関する研觉（第2報），日本造船学会 論文集 No.126（1969） p.357 p.365

15) S.S.Manson : Thermal Stress and Low Cycle Fatigue,McGraw-Hill (1966)

16) D.E.Martin : An Energy Criterion for Low Cycle Fatigue, Trans. ASME, Ser.D, April (1921) p.565 p.571

17) S.S.Manson : Interfaces between Fatigue, Creep and Fracture,NASA TM X-52189（1966）

18) L.F.Coffin, Jr. : Experimental Support for Generalized Equation Predicting Low Cycle Fatigue, Journal of Basic Engineering, Trans. ASME (Series D) December, (1962) 533/537

19）飯田国公、井上:擎、小林佑規：歪制御低サイクル瘦 労における累稹被害（第2報），日本造船学会袷文集、 第123毞、pp.287 296、1968

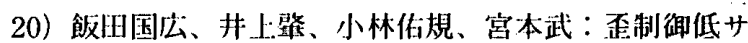
イクル披学に扩ける歪波形の影幚，同上、第125号、 pp.217 225、1969

21）白鳥英亮、小嶓谷洋一：塑性疲れ繦さにおよぼす平 均応力心影響，同上、32巻、238号、pp.886 893、 1966低繰返し数疲れ強さにおよほすす平均応力の影 響，同上、35巻、272号、pp.701 704、1969、塑性 疲れ試験における繰返し㐫力〜ひずみルーブの形 状. 同上、37巻、272号、pp.705 710、1969

22）花井正実、黒羽敬明、吉村浩二、藤田文雄：鋼素材 の低サイクル摭学挙動に関する実験的研究，日本建 筑学会論文報告集、第184号、pp.29 40、1971

23）金属材料技術研究所、疫れデータシート、No.22 (1980)、No.47 (1985)、

24）山口、杉沢、望月：低降伏点鋼及び極低降伏点鋼ひ 材料特性，日本建策学会大会梗概集、1994.9

（1994年10月10日原稿受理，1995年 3 月 1 日採用決定） 